ISSN: 2238-8052

\title{
ENTREVISTA À GEÓGRAFA BEATRIZ MARIA SOARES PONTES - UFRN
}

\author{
INTERVIEW WITH THE GEOGRAPHER BEATRIZ MARIA SOARES PONTES - UFRN
}

Cláudio Jorge Moura de CASTILHO ${ }^{1}$

Entrevista recebida em 23/10/2017 e aceita em 27/11/2017

\section{R E S U M O}

Trata-se de uma entrevista realizada, no primeiro semestre do ano de 2017, pelo Professor Cláudio Jorge Moura de Castilho à Professora Beatriz Maria Soares Pontes, geógrafa atualmente aposentada pela Universidade Federal do Rio Grande do Norte. A entrevista realizou-se da seguinte maneira: primeiramente, elaborou-se o conjunto das questões e, em seguida, as questões foram enviadas por e-mail à referida Professora a fim de que ela pudesse respondê-las livremente.

\begin{abstract}
A B S T R A C T
This interview was carried out in the first semester of 2017 by Professor Cláudio Jorge Moura de Castilho to Professor Beatriz Maria Soares Pontes, a geographer currently retired by the Federal University of Rio Grande do Norte. The interview was divided into two moments: firstly, we elaborated the questions, and after we sent them, by e-mail, to Professor Beatriz so that she could answer them freely.
\end{abstract}

\section{Professora Beatriz Pontes, a Senhora poderia falar um pouco sobre a relação da sua} trajetória de vida (pessoal) com a Geografia, levando-lhe a escolher a Geografia como ciência e profissão?

Encontrávamo-nos, ainda, na escola primária (hoje correspondendo ao ensino fundamental) quando logo no início do ano letivo, apresentou-se como Professor de Geografia, o Sr. Léo. Até hoje, lembramos dele como uma pessoa muito fluente quanto aos conhecimentos geográficos, fato que àquela época já havia chamado a nossa atenção. Gostávamos, imensamente, de assistir as aulas do referido professor e, o nosso interesse aumentou, quando ele principiou a ministrar conhecimentos relativos à origem dos lagos. Explicou-nos as características dos lagos de origem vulcânica, tectônica, glaciária e sedimentar, além dos lagos artificiais.

Na oportunidade, solicitou aos seus alunos que desenhassem os diferentes tipos de lagos no caderno de cartografia. Na medida em que desenvolvíamos esta lição de casa, notamos o maior

\footnotetext{
1 Professor Associado do Departamento de Ciências Geográficas da Universidade Federal de Pernambuco, Coordenador do Grupo de Pesquisa Movimentos Sociais e Espaço Urbano, Bolsista de produtividade nível 1D do CNPq. E-mail: claudiocastilho44@gmail.com.
} 
aumento do nosso interesse pelos assuntos geográficos e, após alguns dias, em conversa com o nosso pai, dissemos-lhe que quando fôssemos adulta, seríamos geógrafa.

Desta forma, demos ao longo dos estudos posteriores, particular ênfase à Ciência Geográfica e, quando chegou o momento de prestarmos o vestibular, em Geografia, na Universidade de São Paulo, dedicamo-nos aos estudos com muita concentração, passando para o primeiro ano do curso de Geografia, na aludida Universidade, em 1957.

Ao longo da graduação, fomos aluna de professores de grande conhecimento geográfico que não ficaram apenas nas aulas teóricas, mas, estabeleceram práticas através de várias excursões de estudos, tanto na esfera da Geografia Física, quanto no âmbito da Geografia Humana. Apesar de gostarmos imensamente das aulas de Geomorfologia e Oceonografia, o nosso envolvimento maior foi, sem dúvida, com a Geografia Política, então ministrada pelo Professor Doutor Pasquale Petrone.

Assim sendo, posteriormente, ao longo da nossa carreira, sempre desenvolvemos os nossos trabalhos científicos em três grandes vertentes da Ciência Geográfica: Geografia Política/Geopolítica, Geografia Urbana e Geografia e Meio Ambiente. Das três opções, a que sempre mais gostamos foi a área da Geopolítica, na qual trabalhamos até hoje, mesmo após termos deixado o nosso período ativo, no âmbito da Universidade.

\section{Quais foram os pensadores e as obras fundamentais que influenciaram sua formação acadêmica, em termos teóricos e metodológicos?}

No período em que estivemos na graduação, tivemos a oportunidade de inteirarmo-nos, em ampla escala, do pensamento de muitos geógrafos pertencentes à chamada Geografia Clássica. Assim sendo, quanto à Escola Alemã, familiarizamo-nos com os geógrafos Humbolt, Ritter, Ratzel, Alfred Hettner, Karl Troll, Schluter, Siegfrid Passarge, Leo Waibel, von Thünen, Alfred Weber e Lösch. Na Escola Francesa tivemos contacto com os seguintes pensadores geógrafos: Vidal de la Blache, Lucien Febvre, Élisée Reclus, L. Gallois, Emanuel de Martonne, Henry Baulig, Jean Brunhes, Pierre Deffontaines, Camille Valloux, George Hardy, Max Sorre, Roger Dion, André Chollay, Albert Demangeon e Daniel Faucher. Quanto à Escola Britânica, entramos em contacto com os geógrafos: J. Mackinder e Dudley Stamp. No que concerne à Escola Norte-Americana, os autores mais discutidos e lidos, no decurso da graduação foram os seguintes: George Perkins March, J. W. Powell, Elen Semple, E. Huntington, Carl Sauer e Richard Hartshorne. Finalmente, quanto à Escola Russa, nos envolvemos, em situações distintas com o geomorfólogo Sothawa e o geógrafo russo contestador, Kropotkin.

A Geografia brasileira neste período, já tinha estabelecido a sua institucionalização com a fundação da Universidade de São Paulo, em 1934 e o advento do IBGE, em 1937, além da fundação da Associação dos Geógrafos Brasileiros (AGB). Estudamos quanto ao período de institucionalização, os 
trabalhos científicos dos geógrafos Pierre Mombeig e Pierre Deffontaines. No que concerne ao Departamento de Geografia, no período da nossa graduação, fomos aluna dos geógrafos brasileiros, a seguir arrolados: Aroldo de Azevedo, João Dias da Silveira, Ari França, Dirceu Lino de Mattos, José Ribeiro de Araújo Filho, Nice Lecocq Müller, Renato da Silveira Mendes, Aziz Nacib Ab’Sáber, Pasquale Petrone e Josué de Castro. Ainda nesta época, no âmbito da Universidade do Brasil, entramos em contacto com os geógrafos que alí trabalhavam: Victor Ribeiro Leuzinger, Hilgard O’Railly Sternberg e Jean Tricart.

No que tange à contribuição do IBGE, no Pós-Segundo Conflito Mundial, tivemos a oportunidade de inteirarmo-nos dos trabalhos científicos dos geógrafos daquela instituição: Orlando Valverde, Eloisa de Carvalho, Teixeira de Freitas, Fábio de Macedo Soares Guimarães, Pierre Dansereau, Walter Albert Egler, Dora do Amarante Romariz e Terezinha de Castro. Além dos supracitados, ainda estudamos os trabalhos desenvolvidos pelos geógrafos: Michel Rochefort (que foi, posteriormente, o nosso orientador na Dissertação de Mestrado que desenvolvemos na Sorbonne, isto é, Universidade de Paris I), Bernard Kayser, Pierre George, M. Philliponneau, R. Guglielmo, Yves Lacoste, Jean Dresch e Claude Reffestin.

Todavia, quando a Geografia brasileira começou a buscar novos paradigmas, tendo em vista os novos impactos da tecnologia sobre o conhecimento, emergiu a Geografia Quantitativa, na qual destacaram-se: Michael Chrisholm, Richard Chorley e Hettner, os quais nos seus trabalhos utilizaram a pesquisa operacional, a cibernética e a Teoria dos Jogos. Naquela época, surgiu, também, a Geografia Comportamental e da Percepção que teve como geógrafa de maior expressão, a Professora Lívia de Oliveira e, como grande referência, o geógrafo chinês, radicado nos EUA, Yi-Fu Tuan.

Posteriormente à fase anterior, destacou-se a preocupação com a Ciência Geográfica não só em termos de novas teorias, como também, a possibilidade do estudo da sua atuação, no âmbito social.

Assim, com a emergência desta nova preocupação começaram os estudos sobre a estrutura e a conjuntura social, os estudos ecológicos, além do advento da Geografia Crítica ou Radical, comprometida, de fato, com a sociedade, bem como tudo o que dizia respeito à referida, em termos de espaço e tempo. Destacamos, igualmente, o advento da Geografia da Complexidade, a partir das ideias de Edgard Morin.

Devemos ressaltar que os autores, bem como os pensamentos expressos em suas produções científicas que familiarizamo-nos, ao longo da nossa trajetória, sob a ótica teórico-metodológica, seguem abaixo consignados:

Alain Lipietz. 0 Capital e seu Espaço.

Alex Fiuza de Mello. Marx e a Globalização.

Alexandre Cheptulin. A Dialética Materialista. Categorias e Leis da Dialética. 
Alexandre Koyré. Estudos de História do Pensamento Científico.

André Dartigues. La Fenomenología.

Antonio Carlos Sant'ana Diegues. O Mito Moderno da Natureza Intocada.

Antonio Carlos Vitte (Org.). Contribuições à História e à Epistemologia da Geografia.

Antonio Christofoletti. Análise de Sistemas Geográficos.

Antonio Gramsci. Concepção Dialética da História.

A Questão Meridional.

Amália Inés Geraiges de Lemos e Emerson Galvani (Orgs.). Geografia, Tradições e Perspectivas: Interdisciplinaridade, Meio Ambiente e Representações.

Ambiens Sociedade Cooperativa. Política e Planejamento. Estado e Lutas Sociais. Intervenções e Disputas no Território.

Armando Corrêa da Silva. Geografia e Lugar Social.

Benedito Rodrigues de Moraes Neto. Marx, Taylor, Ford. As Forças Produtivas em Discussão.

Bertha Becker et al. Tecnologia e Gestão do Território.

Caio Lóssio Botelho. Capítulos Universais da Geografia Monística.

Carla Morsello. Áreas Protegidas Públicas e Privadas: Seleção e Manejo.

Carlos Augusto de Figueiredo Monteiro. Geossistemas. A História de uma Procura.

Carlos Rodrigues Brandão (Org.). Repensando a Pesquisa Participante.

Celso Furtado. Teoria e Política do Desenvolvimento Econômico.

Ciro Flamarion S. Cardoso e Héctor Pérez Brignoli. Os Métodos da História. Introdução aos Problemas, Métodos e Técnicas da História Demográfica, Econômica e Social.

David Harvey. O Novo Imperialismo.

Espaços de Esperança.

E. Ann Kaplan (Org.). Mal-estar no Pós-Modernismo.

Ernest Mandel. A Crise do Capital. Os Fatos e sua Interpretação Marxista.

Felix Kaufmann. Metodologia das Ciências Sociais.

Friedrich Engels. A Dialética da Natureza.

Fritjof Capra. Uma Nova Compreensão Científica dos Sistemas Vivos.

Gabriel Eduardo Vitullo. Teorias da Democratização e Democracia na Argentina Contemporânea.

Gláucio José Marafon et al. Pesquisa Qualitativa em Geografia: Reflexões Teórico-Conceituais e Aplicadas.

Henri Lefebvre. Compreender o Pensamento de Karl Marx.

Horácio Capel Saez. O Nascimento da Ciência Moderna e a América. O Papel das Comunidades Científicas, dos Profissionais e dos Técnicos no Estudo do Território.

I. I. Rubin. A Teoria Marxista do Valor. 
Iná Elias de Castro, Paulo César da Costa Gomes e Roberto Lobato Corrêa (Orgs.). Brasil: Questões Atuais da Reorganização do Território.

Geografia: Conceitos e Temas.

Jean Piaget. Lógica Y Conocimiento Científico.

João Emanuel Evangelista. Teoria Social Pós-Moderna. Introdução Crítica.

João Manuel Cardoso de Mello. 0 Capitalismo Tardio. Contribuição à Revisão Crítica da Formação e do Desenvolvimento da Economia Brasileira.

Joel Martins, Maria Fernanda S. Farinha e Beirão Dichtchekenian (Orgs.). Temas Fundamentais de Fenomenologia.

Karel Kosík. Dialética do Concreto.

Karl Marx. O Capital.

Karl R. Popper. A Lógica da Pesquisa Científica.

Lúcia Helena de Oliveira Gerardi e Bárbara-Christine Nentwig Silva. Quantificação em Geografia.

Ludwig von Bertalanffy. Teoria Geral dos Sistemas.

Luis Boada. O Espaço Recriado.

Manuel Correia de Andrade. Uma Geografia para o Século XXI.

Marcelo Escolar. Crítica do Discurso Geográfico.

Marcos Aurélio Saquet. Abordagens e Concepções de Território.

Maria Auxiliadora da Silva, Rubens de Toledo Jr. e Clímaco César Siqueira Dias (Orgs.). Encontro com o

Pensamento de Milton Santos. O Lugar Fundamentando o Período Popular da História.

Marta Harnecker. 0 Capital: Conceitos Fundamentais.

Marta Harnecker e Gabriela Uribe. Luta de Classes.

Massimo Quaini. Maxismo e Geografia.

Max Weber. Metodologia das Ciências Sociais.

Meri Lourdes Bezzi. Uma (Re)visão Historiográfica da Gênese aos Novos Paradigmas.

Michel Focualt. A Microfísica do Poder.

Michel Phlipponneau. Geografia e a Ação. Introdução à Geografia Aplicada.

Michel Rochefort. Redes e Sistemas. Ensinando sobre o Urbano e a Região.

Milton Santos. Por uma Economia Política da Cidade. 0 Caso de São Paulo.

. Espaço e Método.

Por uma Geografia Nova.

. O País Destorcido.

. O Trabalho do Geógrafo no Terceiro Mundo.

Técnica, Espaço, Tempo.

. Metamorfoses do Espaço Habitado. 
. Da Totalidade ao Lugar.

. Urbanização Brasileira.

. Por uma Outra Globalização. Do Pensamento Único à Consciência Universal.

. 0 Espaço Dividido.

Ministério do Planejamento e Coordenação Geral. Fundação IBGE. Geografia Quantitativa.

N. Bukharin. Tratado de Materialismo Histórico.

Neil Smith. Desenvolvimento Desigual. Natureza, Capital e a Produção do Espaço.

Nelson Senra. O Saber e o Poder das Estatísticas. Uma História das Relações dos Estaticistas com os

Estados Nacionais e com as Ciências.

Norberto Bobbio et al. Marxismo e o Estado.

P. James / E. Taaffe / A. Pred / J. Gottmann / H. Mayer / J. Hart / W. Kollmorgen / G. Reckord / L. Alexander / E. Ullman / S. Cohen / N. Ginsburg / G. White / J. Blaut / K. Stone / R. Alexander / C. Kohn / J. Borchert / G. Kish. Geografia Humana nos Estados Unidos.

R. J. Johnston. Geografia e Geógrafos. A Geografia Humana Anglo-Americana desde 1945.

Richard J. Chorley e Peter Hagget. Modelos Socioeconômicos em Geografia. . Modelos Físicos e de Informação em Geografia.

Robert Lenoble. História da Ideia de Natureza.

Roger Bastide (Coordenador). Usos e Sentidos do Têrmo "Estrutura” nas Ciências Humanas e Sociais.

Rogério Haesbaert. Territórios Alternativos.

Roy E. Jones. Análise Funcional da Política.

Ruy Moreira. Sociedade e Espaço Geográfico no Brasil.

. Pensar e Ser em Geografia: Ensaios de História, Epistemologia e Ontologia do Espaço Geográfico. . A Presença do Espaço na Teoria e na Prática Geográfica.

. Sociedade e Espaço Geográfico no Brasil. Constituição e Problemas de Relação.

. O Pensamento Geográfico Brasileiro. As Matrizes da Renovação.

. O Pensamento Geográfico Brasileiro: As Matrizes Clássicas Originárias.

Ougária C. F. Matos. O Iluminismo Visionário: Benjamin, Leitor de Descartes e Kant.

Santiago Ramon Y Cajal. Regras e Conselhos sobre a Investigação Científica.

Severino Cabral. Brasil Megaestado. Nova Ordem Mundial Multipolar.

Simpósio Realizado no Departamento de História da Faculdade de Filosofia, Letras e Ciências Humanas

- USP. Organização: Osvaldo Coggiola. Marx e Engels na História.

Silvia Fernanda de Mendonça Figueirôa. As Ciências Geológicas no Brasil: Uma História Social e Institucional, 1875-1934.

Suzi Huff Theodoro (Org.). Conflitos e Usos Sustentável dos Recursos Naturais.

V. Lenin. O Imperialismo: Fase Superior do Capitalismo. 
Yves Lacoste. Geografia do Subdesenvolvimento. Geopolítica de uma Crise.

Zeny Rosendahl e Roberto Lobato Corrêa (Orgs.). Espaço e Cultura: Pluralidade Temática.

Apesar dos conhecimentos adquiridos no período universitário, bem como nos tempos que o sucederam, observamos que teríamos necessidade de conhecermos muito bem a estrutura socioeconômica do nosso país, correspondente ao período posterior ao Segundo Conflito Mundial, até os dias atuais e a natureza do capitalismo que presidiu toda a segunda metade do Século XX e o início do Século XXI. A nossa percepção resultava de novos desafios que passamos a enfrentar, no âmbito da Secretaria de Economia e Planejamento do Estado de São Paulo, onde trabalhamos como geógrafa profissional, além dos períodos subsequentes quando retornamos à Universidade. Então, deparamonos com vários trabalhos de assessorias e consultorias, bem como a nossa presença como representante da Universidade, na qual trabalhávamos, no Conselho Municipal de Saúde (Rio Claro), no Conselho Comunitário (junto à Prefeitura de Rio Claro) e no Conselho do Patrimônio Histórico, Arqueológico, Artístico e Turístico do Estado de São Paulo, junto à Secretaria da Cultura do aludido Estado.

As longas reflexões estão a seguir explicitadas:

\section{Período da Secretaria de Economia e Planejamento do Estado de São Paulo}

Estudando, detidamente as estratégias consagradas pelo governo paulista, atestamos que as mesmas tinham como suporte teórico as teorias de localização, tais como a dos polos de desenvolvimento, a dos lugares centrais e a da propagação das ondas de inovações. Tratava-se, portanto, de um projeto teórico positivista, o que, aliás, foi comprovado por nós, através dos estudos que realizamos no âmbito da Secretaria de Economia e Planejamento, com a finalidade de executarmos os programas e projetos encaminhados por aquele órgão, no período em que lá trabalhamos.

Sendo a urbanização e a regionalização temas associados e, ao mesmo tempo, relacionados ao processo de desenvolvimento econômico, não seria possível refletirmos em torno da questão do espaço e, inclusive, de políticas urbanas sem um enfoque sobre as teorias e modelos de desenvolvimento regional.

Pelo prisma de algumas dessas teorias, a cidade é um foco de concentração de atividades e de irradiação de inovações, duas funções essenciais no contexto do processo de desenvolvimento. Em relação à primeira (concentração de atividades) estão associados todos os conceitos de localização, economias de escala, mercado de consumo para numerosas atividades produtoras, concentração de mão de obra, etc., e em relação à segunda (irradiação de inovações) estão associados os conceitos de 
difusão de inovações, com suas implicações na hierarquia e no espaçamento dos centros urbanos e na capacidade multiplicadora dos mesmos.

Os geógrafos têm desenvolvido, talvez de forma ainda incompleta, um conjunto de teorias que procuram explicar as relações do sistema de cidades com o processo de desenvolvimento econômico. Estas teorias são essencialmente derivativas, isto é, expansões de teorias originadas, principalmente na economia e nas quais o processo espacial é tornado mais explícito.

As cidades têm uma estrutura e mantêm relações com outras cidades e com populações em torno das mesmas, formando um sistema. Em primeiro lugar, a cidade, ela própria sendo um sistema, pois umas partes da referida interagem com outras, de várias maneiras. Em segundo lugar, as cidades entre si e a economia espacial que elas organizam, articulam e dinamizam.

A primeira tomada de posição de natureza filosófica que ventilaremos, tendo em vista que a teoria do desenvolvimento regional atenta ao espaço, é a que diz respeito à natureza do processo de crescimento, tomada no sentido Perroux-Hirschmann, de que ela é essencialmente desequilibrada inicialmente. Crescimento rápido na produção total e crescente concentração beneficiada e propiciada por economias de escala têm gerado sempre um padrão estrutural comumente descrito como núcleoperiferia. 0 mecanismo é o mesmo descrito por economistas, como Myrdall ou Hirschmann, e é esta concentração que acumula momentum, gera demandas de matérias primas nas regiões periféricas e com esta demanda se inicia um processo de crescimento nas mesmas, diferenciado e especializado, segundo a natureza dos recursos regionais. À medida que o Núcleo Básico se desenvolve e se transforma, os seus níveis de renda vão aumentando, a um ponto em que numerosas indústrias vão sendo tornadas não competitivas e literalmente expulsas, filtrando, por assim dizer, para núcleos não metropolitanos, onde elas não só vão encontrar tetos salariais mais baixos, como poderão gerar impulsos de crescimento nos mesmos.

O corolário deste mecanismo é um crescimento equilibrado do sistema de cidades, cujos tamanhos vão aumentando na medida em que suas funções vão se diversificando, criando um sistema interdependente e articulado. 0 problema crucial é que nem sempre este mecanismo funciona de forma irrestrita, gerando aquilo que Berry denomina de "deviation amplifing process" que seria, segundo Myrdall, uma forma de causação circular cumulativa.

Observaremos que está contida em tais teorias a questão da continuada concentração de crescimento econômico nas grandes cidades que, para muitos, é considerada necessária para capturar economia de escala e acumular externalidades, sob a forma de infraestrutura social e econômica, porquanto elas constituem, por seu turno, os pré-requisitos para o crescimento posterior, necessário à geração de recursos imprescindíveis à superação das inadequações institucionais que hoje caracterizam os países subdesenvolvidos. 
Outros contestam tais argumentos e acrescentam que as inadequações institucionais são o produto de crescimento e desenvolvimento em poucas grandes cidades superurbanizadas, agindo de forma parasítica sobre seus interiores, drenando a vitalidade da sociedade como um todo, equilibrando-se em um estado de hiperurbanização, que somente pode ser combatido com uma política deliberada de descentralização.

Foi, sem dúvida alguma, o envolvimento dos técnicos governamentais com tais concepções que os levaram a defender, no âmbito da política urbana definida no II PND, a ideia de centros de crescimento, com argumentos de que os custos de urbanização em centros de tamanho intermediário provavelmente demandariam investimentos de infraestrutura menos vultosos que nos grandes centros. Além disso, estes centros de tamanho intermediário não só trariam novos recursos ao processo de desenvolvimento, como, pela simulação do processo espontâneo de difusão hierárquica, superariam muitas das restrições eventualmente impostas ao seu funcionamento normal, portanto, agindo de forma a induzir o processo espontâneo. Polos de desenvolvimento passam, assim, a constituir um elemento essencial na definição de estratégias de desenvolvimento.

No que diz respeito ao polo de crescimento de Perroux, um problema ainda não foi solucionado satisfatoriamente: é o da transformação de um espaço topológico abstrato, em um espaço geográfico. Lasuen, um dos economistas espaciais mais atuantes no assunto, procurou desenvolver as ideias originais de Perroux, dando às mesmas, seu sentido inicial, de espaço econômico abstrato, através de uma tipologia tríplice definida pelo próprio Perroux: espaço como área de planejamento das unidades de decisão; espaço como campo de forças, atuando sobre as unidades de decisão e espaço como campo de objetos homogêneos.

Finalmente, o estudo das teorias de desenvolvimento regional mostrou uma interdependência do processo de crescimento econômico e a estrutura espacial. Uma tal integração é a intenção explícita subjacente à teoria de desenvolvimento polarizado de Friedman. Na verdade, sua teoria, retratando um sistema hierárquico de centros de crescimento, aproxima-se da ideia de uma teoria dinâmica de localidades centrais e abarca contribuições importantes da teoria moderna de crescimento urbano. Essa tendência da teoria de desenvolvimento regional vem de encontro aos recentes esforços despendidos pelos geógrafos interessados no estudo do processo de urbanização e da teoria da rede urbana.

Inicialmente, a teoria do "polo de crescimento" foi vinculada às ideias de Perroux, tendo sido, portanto, a linha de pensamento que concentrou a atenção da crítica.

Cumpre salientar que a formulação original do conceito de "polo de crescimento" surgiu como um componente integral da teoria de Perroux sobre o crescimento econômico. Sua noção básica de que o crescimento não aparece simultaneamente em todo lugar, mas em um número limitado de "polos de crescimento", os quais transmitem impulsos de crescimento para o resto da economia, não possui 
conotações de área. Seu "polo de crescimento" corresponde ao setor dinâmico da economia (industrie motrice) ou a uma empresa dinâmica, usualmente de grande porte (firme motrice), que exerce uma dominância (através de relações de input e output) sobre outros setores ou empresas. Além disso, os inter-relacionamentos entre empresas e indústrias são considerados em um espaço abstrato, funcional. Todavia, posteriormente, o conceito foi aplicado ao estudo dos aspectos espaciais do crescimento econômico. As localizações das empresas ou indústrias dinâmicas e os efeitos induzidos que se supunha ocorrer na área geograficamente contígua (região) começaram a ser tratados como polos de crescimento. A transição do espaço econômico abstrato para o espaço geográfico sempre foi o ponto fraco da teoria de "polo de crescimento" espacial, já que as regras de transformação de um espaço para o outro nunca foram satisfatoriamente formuladas. A teoria não apresenta respostas à questão de onde e por que aparecem os efeitos de crescimento que ocorrem nos "polos de crescimento", no que concerne à localização e funcionamento dos próprios "polos de crescimento" (geográficos).

Outro tipo de crítica contra a teoria de "polo de crescimento" foi levantado por J. R. Lasuen. Ele sustenta que o defensor dessa teoria desenvolveu um interesse unilateral no estudo de relações interindustriais; a atenção foi focalizada principalmente sobre o tamanho das empresas, da "dominância" em termos de relação de input-output, dos efeitos multiplicadores etc. E a sua técnica principal repousa na análise de input-output. Assim, o campo de visão se restringiu e a utilidade do próprio conceito de polo de crescimento foi limitada. Lasuen ainda ressalta: nas raízes da formulação original do conceito de polo de crescimento, situa-se a ideia central de teoria de Schumpeter sobre o crescimento econômico, que salienta a importância das inovações como motores de mudança. As aplicações posteriores da ideia de polo de crescimento negligenciaram esse entendimento básico do funcionamento do mecanismo do progresso econômico. Segundo Lasuen o preço mais alto pago pela escola francesa, na restrição de sua análise à técnica inter-industrial, é que ela esvaziou o conceito de polo de crescimento de seu significado original, temporal e dinâmico e o substituiu por conteúdo estático e/ou estático-comparativo.

Lasuen observou que se considerarmos o processo de desenvolvimento econômico como um processo de adaptação de conjuntos sucessivos de inovações, devemos concluir que os fatores críticos de desenvolvimento devem ser os que determinam esse processo, que podem ser encarados como compostos de três subprocessos: a) geração de inovações; b) difusão do conhecimento dessas inovações e c) o alastramento das adoções. Lasuen, para demonstrar a importância dessa abordagem, procede à análise de como a estrutura organizacional das empresas afeta o processo de adoção de inovações e as consequências para o curso do desenvolvimento econômico no espaço. A linha de raciocínio acima ressaltada é semelhante à abordagem de John Friedman, tal como apresentada em sua Teoria Geral de Crescimento Polarizado. 
A interpretação que, naquela época, já fazíamos do supracitado referencial teórico não nos dava condições de vislumbrar uma adequada estruturação do território nacional, bem como um desenvolvimento socioeconômico que resultasse na melhor distribuição de renda e na atenuação das enormes desigualdades identificadas no seio do povo brasileiro. As nossas preocupações voltavam-se para a interpretação da realidade que tínhamos diante dos nossos olhos, a partir de uma visão completamente diversa da precedente.

O espaço brasileiro pode ser considerado como a articulação das formas espaciais derivadas dos diferentes tipos de dominação que marcaram a história nacional.

Sem dúvida, a aceleração crescente da urbanização gerou aglomerações gigantescas, as quais não eram apenas a expressão quantitativa do conteúdo econômico das cidades brasileiras. Na base do processo de urbanização constatávamos não só a passagem de uma economia agrária para uma economia industrial, mas também, o crescimento do setor terciário.

Assim sendo, a forte concentração humana nas cidades nem sempre resultava do dinamismo econômico das referidas. Era, sobretudo, consequência do êxodo rural.

Constituíram-se, então, grandes concentrações de população sem o desenvolvimento equivalente da capacidade produtiva, impedindo, assim, que parcela expressiva dos migrantes fosse assimilada pelo sistema econômico das cidades.

Tais concentrações manifestaram, também, as características do desenvolvimento desigual, porque ocorreram, sobretudo, nas grandes cidades, seguindo um duplo processo de absorção: do campo por parte das cidades e das cidades pequenas e médias pelas grandes aglomerações.

Esta evolução era perfeitamente lógica se considerássemos que as transferências de população nem sempre foram suscitadas pelo dinamismo produtivo, mas pela concentração progressiva das massas rurais e dos habitantes das pequenas cidades que fugiram da miséria e da ociosidade. 0 resultado foi a desarticulação da rede urbana, refletindo as crises sociais e econômicas e, evidenciando a preponderância desproporcional das grandes aglomerações e, em particular, a concentração do crescimento urbano numa grande região metropolitana, a qual passou a deter a direção econômica e política do país (São Paulo).

A aludida evolução acarretou, também, o fortalecimento da distância social e cultural entre a sociedade urbana e o mundo rural, que permaneceu atrasado, entrando num processo de desintegração. A esta crescente distância econômica, social e cultural, entre as cidades e o campo, acrescentou-se a persistência, no campo, de uma estratificação social, mais acentuada do que nas cidades. Além disso, uma forte diferenciação interurbana entre as antigas e novas populações residentes foi descrita "ideologicamente" sob o termo de marginalidade urbana.

Esta "marginalidade" era ecológica, no sentido de que manifestava simultaneamente a segregação residencial do espaço urbano e a incapacidade do sistema de produção de habitações para 
considerar as necessidades sociais quando esta demanda não era rentável. Outro problema, muito mais complexo, foi o estabelecimento das relações entre esta situação, no que concernia à habitação e ao lugar ocupado por esta população, no âmbito do sistema produtivo, na estratificação social, nos processos ideológicos e no jogo político.

Portanto, o desenvolvimento da segregação interurbana e a constituição de vastas zonas ecológicas chamadas marginais, num processo de urbanização selvagem, constituíram os fatos concretos mais marcantes da urbanização dependente brasileira.

A dependência não é um simples estado de "submissão", do mais fraco em relação ao mais forte, mas uma relação estrutural definida, sobretudo, pela articulação das relações de classe em duas sociedades ou conjuntos de sociedades. Uma sociedade é dependente quando a articulação da sua estrutura social, ao nível econômico, político e ideológico, expressa relações assimétricas com outra formação social que ocupa, em face da primeira, uma situação de poder. Por situação de poder entendemos o fato de que a organização das relações de classe na sociedade dependente encontra sua lógica no exterior dela mesma, expressando o modo hegemônico da classe social que ostenta o poder na sociedade dominante.

Se é verdade que o processo de urbanização é formado pelas relações de dependência, não poderíamos conceber estas relações em sentido único, como se a estrutura social, assim organizada, pudesse se desenvolver sem contradições. Isto significava que a urbanização dependente expressava também os efeitos das crises do sistema de dominação e as respostas sociais e econômicas suscitadas nas sociedades dependentes.

Assim, a crise de 1929 e a fusão dos mecanismos do mercado mundial, com a situação criada no plano econômico e no plano das relações de classes, estava na base de uma tentativa de porte, por parte da burguesia local e do regime então vigente, para estabelecer uma economia de substituição das importações, mediante o desenvolvimento de indústrias de transformação e de consumo para o mercado interno.

A implantação de tais indústrias, todavia, dependia estreitamente da mão de obra urbana e, sobretudo, do mercado potencial das grandes aglomerações às quais estas indústrias eram destinadas. Esta industrialização, ainda que limitada, suscitava uma expansão mais importante dos "serviços", possibilitando a absorção parcial da mão de obra e, ao mesmo tempo, a ampliação do mercado.

Este processo de industrialização nacional reforçou, consideravelmente, as aglomerações existentes e acelerou o crescimento urbano, sem provocar um fluxo migratório excessivo, na medida em que este desenvolvimento não se fazia por pressões exteriores, mas partia da necessidade de um certo equilíbrio econômico definido no quadro brasileiro. Assim, as taxas de crescimento urbano do país, que realizou um esforço importante no período de substituição das importações, são mais elevadas do que antes, indicando o efeito da industrialização sobre as grandes aglomerações, porém 
menos elevadas que as das décadas de 1950-1970, quando a penetração imperialista provocou a explosão das estruturas tradicionais, trazendo às cidades as populações do campo.

O espaço brasileiro, constituído após a Segunda Grande Guerra, esteve, sobretudo, sob o efeito das novas formas de dominação econômica imperialista. De fato, a tentativa de construção de uma economia nacional relativamente duradoura foi sepultada em face da reversão maciça do capital internacional, que, a partir da crise assim criada, desenvolveu o mercado interno e efetuou o processo de substituição das importações ao criar laços de dependência tecnológica, financeira e de decisão econômica.

Tratava-se, portanto, da modernização do aparelho produtivo do país, com uma transformação profunda do secundário, cuja parte ocupada pelo setor moderno cresceu com uma alta tecnologia, forte produtividade e fraca absorção de mão de obra. Estas transformações foram realizadas através da intervenção de grandes empresas multinacionais, cujas decisões eram tomadas em função de uma estratégia mundial e cuja lógica escapava à economia brasileira e à conjuntura de cada formação social.

Podemos, assim, compreender os efeitos desagregadores no interior da sociedade, na medida em que os diferentes fragmentos produzidos pela desintegração e pela desarticulação nacionais foram recompostos, no seio de uma integração e de uma orientação em escala internacional, a partir dos interesses das grandes empresas.

A essa etapa do capitalismo internacional (imperialista) correspondeu também um novo papel do Estado. Os Estados imperialistas, principalmente os Estados Unidos, através da assistência técnica, da ajuda econômica e da supervisão militar e política, trabalharam em função dos interesses do conjunto do sistema de dominação estabelecido.

Por outro lado, os Estados nacionais (Brasil), na medida em que baseavam sua legitimidade na capacidade para assegurar um crescimento econômico cujo controle lhes escapava, passaram a ser os negociadores entre a burguesia local e os monopólios internacionais e distribuidores das condições de rentabilidade desta via de crescimento, na dependência.

Ao nível das classes sociais e no âmbito das suas clássicas contradições apareceu um novo antagonismo entre as massas integradas, de formas diversas, ao setor moderno integrado sob a égide dos monopólios, na dinâmica geral do capitalismo em escala mundial. Assim, as massas foram cada vez mais afetadas pela decomposição interna da sociedade nacional, sobretudo aquelas, que permaneceram atreladas à esfera do sistema produtivo não rentável, na estratégia local das empresas multinacionais.

O novo modo de articulação dependente, em graus diversos, foi dominante no Brasil, principalmente a partir de 1970, produzindo efeitos fundamentais nas formas e nos ritmos do espaço.

O impacto da nova industrialização dependente reforçou consideravelmente a distância entre as cidades e o campo, entre as grandes aglomerações e pequenas cidades, de tal forma que as 
disparidades dos níveis de vida pareceram, à primeira vista, um dos fatores que ocasionou a aceleração considerável da urbanização, em caráter relativamente recente.

Além disso, muitos insistiram sobre a atração exercida pelos novos valores culturais emitidos e difundidos pela cidade. Todavia, não nos pareceu que estas mudanças nas atitudes, que expressaram a reorganização da personalidade numa nova ordem social, pudessem ser consideradas como motor do processo, a não ser que aceitássemos o postulado ideológico liberal do indivíduo como agente histórico autônomo na origem de toda ação social.

Assim sendo, o essencial era definir esta nova situação social que, ao mesmo tempo, estava na base dos processos de urbanização social e das mudanças no sistema de valores. De fato, a desigualdade cidade-campo, em termos de nível social e cultural sempre existiu, sem que por esta razão ocorressem deslocamentos maciços de população.

O fenômeno central pareceu ser a decomposição da estrutura social agrária, seja em suas atividades produtivas ou nas suas instituições sociais e, de forma mais geral, dos setores econômicos não integrados ao conjunto supranacional constituído. Havia, também, um duplo movimento: nos campos, a racionalização capitalista de certos setores, além da crise e decomposição dos setores tradicionais, acarretando o êxodo rural maciço. Nas grandes aglomerações, o desenvolvimento de um setor moderno que criava um mercado interno limitado, mas em contínua ascensão, suscitava, ao mesmo tempo, uma série de atividades conexas, criadoras de empregos, cujo efeito de atração era infinitamente maior do que a sua capacidade de absorção.

Portanto, ao lado de um núcleo central de urbanização produtiva, com o desenvolvimento de certos serviços dela decorrentes, encontrava-se o efeito destruidor do mesmo processo sobre a maior parte das estruturações produtivas agrárias (migração rural), sobre as atividades industriais não concorrentes (migração urbana) e a formação, em ritmo acelerado, das grandes concentrações "terciárias", onde a ociosidade dava um conteúdo profundo às formas ecológicas ocupadas pelas classes desfavorecidas.

Por outro lado, na medida em que verificávamos a desintegração nacional do sistema produtivo, era lógico que a rede urbana se apresentasse desarticulada e truncada. Entretanto, a sua desarticulação não foi senão o resultado de uma articulação social formada pela sociedade dominante e pela sociedade dependente.

Finalmente, um aparelho de Estado mediador dos interesses do novo sistema de dominação não permitiu o estabelecimento de mecanismos de planejamento, que não puderam estabelecer uma lógica própria das aglomerações da sociedade dependente e que foram ao encontro da lógica geral da dominação. Esta lógica proibia, justamente, uma coerência local que romperia a estratégia do conjunto estabelecido a partir dos centros de decisão supranacionais. As transformações do espaço brasileiro 
refletiram, como foi possível constatarmos, as contradições sociais produzidas pelas formas e ritmos de dominação.

Pelas considerações até aqui levantadas, entendemos que os objetivos do Estado autoritário, ao eleger como marco teórico o projeto de desenvolvimento regional supracitado e as teorias de localização, tinham como intuito, a concretização e agilização do processo econômico capitalista, em nosso país, não divisando apenas interesses internos, mas, ligando-os, significativamente, ao projeto capitalista global, em andamento, naquele período.

\section{Período da Universidade Estadual Paulista}

Efetuando uma retrospectiva, no tempo, sobre a nossa produção científica desenvolvida na UNESP, no período de 1978-1991, cremos que pelo menos quatro grandes questões foram alvo da nossa investigação: a crítica ao ordenamento territorial brasileiro, implementado pelo Estado Militar, a crítica à política urbana em vigor, a abordagem regional numa perspectiva dialética e a questão agrária.

A expansão da economia moderna sobre o território, através de fluxos mais rápidos, facilitou a implantação e a ampliação de empresas transnacionais, facultando-lhes maior competitividade e abertura para o mercado interno. Quanto mais rápido foi o ritmo das mesmas, mais celeremente o espaço nacional foi conquistado, diminuindo, simultaneamente, as possibilidades de uma intervenção do Estado nacional em benefício dos seus interesses.

Dentro deste contexto, o Brasil mostrou uma nova Geografia, através de uma profunda reorganização espacial marcada por formas de agricultura capitalista, ao lado de formas residuais anteriores e de formas de transição. Verificamos uma tendência à concentração da propriedade, dos meios de comercialização, escoamento da produção e da população nos grandes centros urbanos, enquanto eram, gradativamente, desativadas as zonas rurais antigas e as pequenas cidades.

A complexa divisão do trabalho e a diversificação do consumo em toda parte contribuiu para o aumento do nível e da importância dos centros urbanos de médio porte, cujos contingentes populacionais não pararam de crescer.

Por outro lado, houve um aumento do número de cidades milionárias (em termos populacionais), ao mesmo tempo em que, na área "core" do país, as grandes cidades continuaram a se expandir. Simultaneamente, a própria região "polarizada" em apreço ampliou-se e diversificou-se em face das incessantes mudanças de função entre as diversas frações do seu espaço.

Um espaço, assim constituído e profundamente marcado por uma composição técnica e orgânica do capital mais elevada, por uma especialização funcional mais acentuada e uma fluidez muito maior, facilitou uma seletividade maior na captação da mais-valia, uma marginalização de 
médias e pequenas empresas, a transnacionalização da economia, um maior desemprego e uma redução da parte da mais-valia produzida que caberia ao Estado, o qual, por essa razão, se tornou incapaz de atenuar a problemática social, mais agravada ainda pela carência de recursos.

Observamos, também, uma tendência da pobreza em se concentrar no polo da Nação, ao mesmo tempo em que comprovamos a dispersão dos pobres para criar as condições materiais da nova produção. Atestamos a presença de uma classe média necessária ao enquadramento da modernização e de uma classe privilegiada, geograficamente externa ao país, estreitamente vinculada às empresas transnacionais que ocuparam o território brasileiro e associada à burguesia nacional e à tecnoburocracia pública e privada. Tal situação acarretou preocupações por parte de certos setores envolvidos com a integridade e a segurança do país. Assim sendo, a independência e a sobrevivência nacionais não poderiam ser logradas, mediante o empobrecimento de camadas populares, do trabalho alienado em todo o território e da presença do grande capital em parceria com o Estado, em face dos grandes interesses do mundo capitalista contemporâneo.

Portanto, no espaço brasileiro, o impacto das forças externas foi preponderante em todos os processos. Essas forças externas tinham uma lógica que era interna às instituições e às empresas interessadas, mas externa em relação ao país. As instituições e empresas que impunham inovações técnicas ou organizacionais tinham objetivo comum: a acumulação de capital.

Para facilitar a instalação de atividades exógenas, o Estado brasileiro construiu infraestruturas, subsidiou atividades modernas e adquiriu bens intermediários em serviços essenciais. Aceitando um modelo de crescimento orientado para fora, o país perdeu o controle sobre as sucessivas organizações do espaço.

Adotando tal ideologia do crescimento, o Brasil preparou o caminho para que as empresas "modernizadoras" pudessem instalar-se e operar, apropriando-se da mais-valia social local que mandavam para fora ou utilizavam para incrementar seus ativos e aumentar, portanto, suas possibilidades de ampliar a própria mais-valia.

Esse mecanismo equivaleu a uma desvalorização dos recursos deixados nas mãos do Estado, ao passo que os recursos que se destinaram às grandes empresas foram supervalorizados. Assim, o Estado se empobreceu, perdendo a sua capacidade para criar serviços sociais ou para ajudar na criação de atividades descentralizadas ou descentralizadoras. A produção passou a não corresponder às necessidades nacionais, estando sujeita a uma concentração acumulativa.

Por outro lado, o consumo também sofreu distorções, sendo utilizado como o melhor vetor do capitalismo internacional para a ocupação de todo o território nacional.

Toda esta situação se refletiu na organização do espaço: macrocefalia, expansão da agricultura comercial ou industrial, em detrimento da agricultura voltada para os interesses do mercado interno e, pela capacidade de comprar equipamentos, bens intermediários e serviços estrangeiros. A produção 
de produtos agrícolas comercializáveis passou a ser uma necessidade porque, se assim não ocorresse, as populações rurais ficariam sem capacidade de participar de uma economia que, cada vez mais, se monetarizava. E, finalmente, a função "regional" das cidades regionais sofreu um declínio porque a revolução dos transportes tornou possível o acesso direto das pequenas cidades às cidades maiores, incluindo as metrópoles. Desta forma, algumas cidades regionais se transformaram em cidades intermediárias, enquanto outras foram rebaixadas à categoria de cidades locais.

Portanto, o espaço brasileiro estava em crise, revelando os problemas vivenciados pela sociedade nacional. Em virtude de sua inserção profunda em uma ordem mundial capitalista, cuja crise se agravava, a sociedade nacional encontrou-se num impasse, sendo a reelaboração do espaço brasileiro um dos propósitos que esta procurou para a sua própria readaptação. Esta reorganização espacial foi o último fruto de uma cooperação jamais interrompida com o sistema mundial capitalista, tanto no plano internacional como no plano nacional.

A política urbana brasileira, no que concerne às suas linhas institucionais e financeiras, enfatizou a questão dos padrões de uso da terra. Do ponto de vista estrutural, a questão da terra urbana no Brasil foi exacerbada por uma alta taxa de urbanização, influenciada pela maneira como a economia rural se desenvolvia. Parcelas extensas de áreas rurais foram ocupadas por modernas unidades de produção, alienando, assim, crescentes parcelas de força de trabalho da agricultura. Este processo global não configurou um sistema alternativo para absorver produtivamente a força de trabalho. 0 resultado, portanto, foi uma grande pressão sobre os centros urbanos existentes. Essas áreas cresceram, nas últimas décadas, tomando preferencialmente uma forma metropolitana. Tal concentração da população urbana em áreas metropolitanas induziu o governo federal a intervir em áreas constitucionalmente reservadas aos poderes locais e regionais.

Outro motivo para a intervenção do poder central foi o comportamento eleitoral das populações metropolitanas brasileiras, que, desde 1972, optaram por votar nas oposições. Além disso, observamos uma crescente concentração de renda não só nas áreas urbanas, mas entre certos estratos da população.

Esta concentração apresentou-se estruturalmente conectada à natureza do modelo econômico, no qual a apropriação do capital social, gerenciado pelo Estado, tendeu a ser aplicado na produção de bens de consumo sofisticados e equipamentos, desigualmente dispostos nos espaços urbanos.

O funcionamento deste sistema, marcado pela alta concentração de renda e de riqueza, levou a economia urbana brasileira à contradição na qual, em uma economia de mercado, o padrão prevalecente de uso do solo resultava da necessidade de maximizar a taxa de lucro sobre parcela da terra que fosse consistente com sua renda de localização. 0 padrão que prevalecia, entretanto, nada tinha a ver com a realização social máxima da mais-valia. 
Além disso, tal dinâmica estava vinculada a processos mais profundos, mediante os quais uma economia de mercado baseava a sua existência sobre a contradição entre a apropriação privada do excedente social e sua produção socializada.

O Estado, por seu turno, através de seus programas de investimentos e obras públicas foi, sem dúvida, o maior responsável pela valorização das propriedades privadas. Para equacionar as demandas sociais, os investimentos públicos não estavam necessariamente favorecendo a sociedade como um todo, mas apenas, exercendo seu papel nesta cena urbana: manter a segregação funcional e garantir os modos pelos quais a ordem urbana se expandia.

Assim, o Estado, através de suas políticas, redefiniu modos potenciais de extração de renda da terra urbana. A especulação imobiliária não foi a única, mas uma das grandes responsáveis pela baixa qualidade de vida do trabalhador urbano brasileiro. Ao estender a cidade para os limites da zona urbana, ao construir as vilas com seu trabalho nos fins de semana, os trabalhadores ajudaram a valorizar as áreas vazias que ficavam no caminho entre o centro urbanizado e seu bairro desurbanizado.

Finalmente, a presença cada vez mais forte de movimentos sociais urbanos, de caráter autônomo, frente ao Estado, colocou no cenário político brasileiro a questão da politização do espaço.

A politização do espaço urbano significou que as relações sociais, envolvendo um recurso que se apresentava relativamente escasso (o solo), exigiram uma mediação política. Atores privados, colocados em vários níveis do sistema de estratificação capitalista, tinham de entrar em relações de natureza não-econômica com o Estado para o encaminhamento da questão. À primeira vista, pensamos que os movimentos sociais urbanos, de caráter reivindicatório ou não, eram os responsáveis pela politização.

Todavia, também o Estado sempre teve muito a ver com a politização do espaço. As implicações do Estado, quanto à politização do espaço, foram deliberadamente dissimuladas pela tentativa que os agentes estatais fizeram de tornar ideologicamente neutras suas intervenções.

Assim sendo, o controle político da expansão foi fundamental. 0 Estado ao intervir pelo planejamento e pelos investimentos, sobretudo, quando redefiniu padrões de uso do solo das cidades ou quando estabeleceu as normas pelas quais as áreas urbanizáveis deveriam ser ocupadas, estava politizando a questão urbana. Portanto, ele tornou claras as relações de interesse sociais, geralmente conflitantes.

Na abordagem da região, se tomarmos o Brasil como referência, observamos, nos últimos anos, a crescente oligopolização em todos os departamentos produtivos: setor produtor de bens de consumo não duráveis.

Concomitantemente, percebemos um vigoroso e acelerado processo de transformação na atividade agropecuária, com a conformação dos já conhecidos complexos agroindustriais. Apesar da 
crescente conformação de grupos oligopólicos ser comum aos três citados, o movimento particular deste processo em cada um destes setores não foi simultâneo no tempo, nem homogêneo no espaço e, muito menos, envolveu os mesmos agentes econômicos e sociais.

Ao verificarmos as linhas mestras do comportamento espacial, como a permanência dos desequilíbrios regionais, percebemos que estes conviveram com o processo de crescente oligopolização da economia.

Colocamos em discussão que este processo de oligopolização da economia apesar de criar e recriar o espaço regional no tempo, ainda não foi suficiente para o resgate da profunda compreensão do processo regional à luz da História, que implicava na abordagem de questões como: avanço tecnológico desigual, lutas de classes, conflitos culturais e continuadas reformulações políticojurídicas, hegemônicas e ideológicas ao nível dos subespaços nacionais, em relação ao espaço nacional como um todo e, deste, em face do movimento geral do modo de produção capitalista.

Nas reflexões feitas, ponderamos sobre o impacto das novas relações que não determinaram mudanças na organização espacial das formas conteúdo precedentes e com as áreas que, ao receberem o impacto das novas relações, encontraram um novo arranjo interno que permitiu a reprodução das condições anteriores.

Por outro lado, a partir da divisão territorial do trabalho, foi definido o que seria produzido, o progresso técnico, as relações de produção e como seria produzido. A região, portanto, seria uma entidade concreta, resultado de múltiplas determinações, sendo uma especificação da totalidade social.

Os nossos trabalhos no âmbito da Geografia agrária, principalmente, os que foram apresentados nos Seminários Nacionais de Geografia Agrária, tinham a preocupação de resgatar e refletir a forma como o Estado militar conduzia as políticas públicas referentes à área em apreço.

Assim sendo, a fronteira agrícola era vista pelo Estado militar como área potencial, como um espaço que oferecia condições à expansão de atividades relacionadas à agropecuária. Três elementos foram fundamentais na delimitação desse espaço potencial: o funcionamento, nele, de mercados, notadamente de produtos, de trabalho e de terras; o desenvolvimento de sistemas de transportes e a disponibilidade de terras a serem ocupadas.

Dentro do espaço da fronteira ocorriam surtos de atividade, denominadas frentes. As frentes avançavam e se retraíam nesse espaço, respondendo às mudanças nos seus elementos determinantes, num processo dinâmico e multifacetado.

Este encaminhamento conceitual facultou-nos o entendimento dos fatores na expansão da fronteira, tanto no período em que o crescimento da produção agropecuária dependia quase que exclusivamente da incorporação de novas terras, como no período mais recente, de relação menos direta entre a evolução da fronteira e a produção agropecuária. 
No caso explícito do Nordeste brasileiro, que ocupou largo espaço das nossas reflexões, a questão agrária foi discutida, sobretudo, focalizando o Polonordeste, ao qual sucedeu o Projeto Nordeste, este último tendo como aspecto fundamental a política do pequeno produtor rural.

Nesse sentido, foram analisadas as propostas do Estado para a pequena produção, a assistência técnica e creditícia, aos problemas afetos à educação e à saúde do homem inserido na pequena produção, bem como as formas altamente discutíveis do processo de planejamento público tratar os aspectos acima mencionados. Foram discutidos, também, os interesses da classe dominante em relação ao mundo rural, os graves problemas fundiários do Nordeste, bem como os Planos Nacionais de Reforma Agrária e os aspectos relativos à área nordestina, neles inseridos.

\section{A Ciência Geográfica Brasileira, a partir de 1978}

No final da década de 1970, assistimos a um período de substanciais mudanças e transformações na história do pensamento geográfico nacional. Tais reformulações tiveram guarida no 3o Encontro Nacional de Geógrafos, realizado em Fortaleza, em 1978. Naquela oportunidade, procedentes do exílio, vários geógrafos que haviam sido profundamente penalizados pela incompatibilidade das suas posições e ideias, em relação ao Estado militar, começaram a discutir, com veemência, novas ideias e propósitos no âmbito da nossa ciência, assim como no que concernia aos destinos futuros da Nação brasileira.

O debate teórico-metodológico emergente no Encontro de Fortaleza questionou, significativamente, o que, até então, vinha sendo diligenciado, no âmbito da Geografia no Brasil. Assim sendo, os questionamentos envolveram não apenas a Geografia Clássica, como também, a Geografia Quantitativa e Sistêmica, amplamente utilizada não apenas no IBGE, como também em outras esferas geográficas nacionais.

Em conformidade com as novas ideias, era anunciado o advento do projeto dialético, o qual traria à lume as questões relativas à produção do espaço, às desigualdades socioespaciais, ao trabalho, às classes sociais, à pobreza, à justiça social, à desafiadora questão da interface natureza-sociedade e à questão ambiental, visualizados, criticamente, no âmbito do sistema capitalista em vigor.

Apesar de concordarmos com tais mudanças referentes ao conteúdo do pensamento geográfico brasileiro, devemos aqui consignar a nossa discordância em relação a determinados encaminhamentos que tiveram lugar no decurso do supracitado Encontro e mesmo, após a sua concretização. Na ocasião, os geógrafos físicos, além de outros dedicados à Geografia Humana, de uma maneira geral, e, de forma marcada, os geógrafos do IBGE, foram amplamente questionados por parte daqueles que eram os artífices do novo paradigma geográfico. 
Entendemos que os colegas acidamente censurados não deveriam ter sido tratados de forma tão contundente. Na verdade, havia, entre eles, pessoas sérias sob a ótica humana e profissional, os quais desenvolviam suas atividades nas instituições a que estavam atrelados sem, obrigatoriamente, envolverem-se com os propósitos do Estado militar, conforme lhes foi dito, neste período de grandes debates. Além disso, ponderamos que os colegas questionados tinham o direito de efetuarem suas escolhas teórico-metodológicas em sintonia com os objetivos dos trabalhos que realizavam. Não podemos aceitar o tolhimento do legítimo direito de pensar livremente, sobretudo, quando estamos refletindo sobre a ciência. Nunca será possível a expansão e a geração do conhecimento sem a liberdade. Na verdade, seria precipitação julgarmos, de maneira geral, o conjunto dos nossos pares, porquanto se entre os mesmos existiam aqueles que estavam em sintonia com o Estado de exceção, não seria menos verdade, que haviam aqueles que, apesar de trabalharem para a esfera governamental, discordavam da forma como, àquela época, era conduzida a vida nacional.

Concomitantemente com as aludidas mudanças, verificamos grandes questionamentos no que tangia à estrutura e aos estatutos da Associação dos Geógrafos Brasileiros. Neste período, na condição de presidente da seção local de Presidente Prudente da AGB, produzimos com os demais companheiros da diretoria local, um novo projeto de estatuto.

A seção local de São Paulo fez o mesmo e, no transcorrer de uma reunião histórica, levada a termo no auditório do Departamento de Geografia da Universidade de São Paulo, foram discutidos os dois projetos, dos quais resultou uma nova proposta de estatuto da AGB nacional. Vivemos, também, nessa ocasião, momentos de angústia e de apreensão, em face da pouca tolerância e abertura evidenciadas por vários colegas presentes, que se feriram mutuamente através de observações extremamente contundentes, o que demandou, posteriormente, um tempo muito dilatado para que, enfim, as feridas fossem gradualmente cicatrizadas.

Possivelmente, o nosso pleno entendimento desse difícil contexto fosse resultado da nossa vivência com as diferentes etapas do pensamento geográfico do nosso país, porquanto, na graduação, na Universidade de São Paulo, convivemos com a Geografia Clássica. Na nossa pós-gradação em nível de mestrado, na Universidade de Paris, estivemos envolvida com os questionamentos sobre o precedente modo de pensar geográfico e o advento da discussão do espaço sob a ótica capitalista e, posteriormente, nos envolvemos com os métodos sistêmicos e quantitativos da Geografia, no decurso da nossa permanência na Secretaria de Economia e Planejamento do Estado de São Paulo. Tal vivência nos deu uma visão muito clara do que estava se consumando, no seio do pensamento geográfico, ao longo da segunda metade do Século XX. Consideramos também ser perfeitamente válido que a ciência geográfica tenha abraçado, ao longo do tempo, diferentes projetos teórico-metodológicos, porquanto, é exatamente nessa diversidade de pensamento que reside a sua grande riqueza. 


\section{Período da Universidade Federal do Rio Grande do Norte}

A nossa entrada na UFRN, em 1992, se consumou num quadro nacional e global diverso daquele que presidiu o nosso compromisso com a Universidade Estadual Paulista. 0 mundo havia se modificado significativamente, não apenas com a queda do mundo socialista, mas também, com a presença marcante do sistema de acumulação flexível, no âmbito do capitalismo.

Tais redimensionamentos sociais, econômicos e políticos tiveram profundas repercussões no quadro epistemológico da ciência geográfica, na forma de discutir o território, na maneira de refletir os conteúdos da Geografia Política, bem como na forma de conduzir o processo de planejamento nacional, regional e local.

Assim sendo, o planejamento nacional não mais poderia ser conduzido como o fora nos anos precedentes e, sobretudo, sob o manto do Estado militar. As articulações das economias nacionais com a global e as reformas a que estas foram submetidas acenavam com o advento de um planejamento democrático e, não mais, centralizado e imperativo. Estávamos num momento em que o envolvimento dos atores sociais neste processo era absolutamente imprescindível. Sem dúvida, o diálogo entre o Poder Público e a iniciativa privada fez-se sentir no planejamento nacional. Todavia, a presença e a participação da sociedade civil organizada e da população em geral passaram a ser de grande significado.

Assim sendo, a nossa produção científica, ao longo dos anos que permanecemos na Universidade Federal do Rio Grande do Norte, foi mediada por um suporte epistemológico, cujos aspectos fundamentais são arrolados a seguir.

A utilização da energia barata, a organização taylorista do processo de trabalho e consumo maciço constituíam a base funcional do modelo produtivo fordista que, em seus aspectos supraestatais, se apoiava numa configuração keynesiana de Estado.

O denominado "Walfare State" atuava como organizador e construtor do paradigma produtivo fordista, acumulando numerosas funções produtivas diretas, generalização de infraestrutura, manipulando também os recursos normativos e de política econômica que permitiram o funcionamento de mecanismos distributivos, compatíveis com o modelo econômico fordista. Sob o mesmo, a produção se orientava para mercados maciços, com escassa diferenciação de modelos e produtos estandartizados, de ciclo de vida prolongado.

Deste modo, a oferta definia a demanda e, as variações positivas desta, dependiam da ampliação da base de consumidores. 0 núcleo dinâmico deste regime de acumulação estava centrado no complexo metal/mecânico. 
Os mecanismos estruturais do modelo fordista - grandes estabelecimentos para aproveitar economias de escala, contiguidade espacial dos processos produtivos, economias de aglomeração, etc. - estão na base explicativa das formas espaciais que produziu.

Com efeito, a consequência direta da concentração técnica da produção se refletiu também como concentração espacial. Assim, podemos dizer que o regime de acumulação fordista foi protagonista decisivo nos processos de metropolização. Sem dúvida, em sua fase final produziu-se uma certa dispersão concentrada até a periferia, como uma alternativa para recompor - ao menos circunstancialmente - a taxa de lucro, aproveitando a formação de mercados cativos e as substanciais diferenças salariais nas regiões deprimidas dos países capitalistas centrais e nos países em desenvolvimento, nos quais o capital se punha a salvo das organizações sindicais maduras e poderosas dos centros industriais tradicionais.

0 encarecimento de alguns fatores de produção chaves (petróleo e mão de obra) e a incapacidade do setor tecnológico fordista para responder a estas mudanças, redundou numa crise profunda e prolongada da taxa de lucro no setor industrial e estabeleceu limitações ao modelo fordista para seguir reproduzindo-se, enquanto os circuitos financeiros internacionais viviam uma verdadeira hiperexpansão e constituíram o setor de refúgio para o capital de origem industrial, durante os anos setenta, nos países do Norte e nos oitenta, nos países do Sul.

O conjunto de novas tecnologias que começaram a operar como fator de saída da crise não implicou na renovação ou transformação do fordismo, mas sinalizaram o seu esgotamento e superação. Esta transformação tecnológica supôs o surgimento de novos fatores chaves do modelo tecnológico-produtivo. Alguns autores visualizavam o complexo militar-aeroespacial ou o eletrônico (em especial a microeletrônica) como o fator chave do novo modelo.

Aparentemente, o fenômeno seria de maior complexidade e nos pareceu prudente adotar um fator mais envolvente, que estaria representado pela informação, o que implicaria em considerar como eixo do processo os setores da microeletrônica e as telecomunicações como os novos núcleos dinâmicos do paradigma emergente.

Este fenômeno implicou em transformações em todos os níveis, desde as modalidades do desenho dos produtos, até as formas de organização do processo produtivo, passando pelo próprio conteúdo tecnológico dos novos produtos e de suas características.

Deste ponto de vista, visualizamos outro conceito chave do novo paradigma que poderia ser utilizado para denominá-lo: a flexibilidade. Entretanto, para alcançar toda a sua eficácia e eficiência, as novas tecnologias demandavam uma nova organização trabalhista e mudanças profundas nos hábitos e costumes e, particularmente, de consumo. Em definitivo, requeria uma transformação substancial da concepção de Estado, dos seus papéis e de sua relação com a sociedade. A condição de flexibilidade se expressava não só a nível dos bens de capital, dos produtos e das formas de produção e desenho em si, 
mas também, estendia-se aos volumes a produzir, às relações e conexões interpessoais, particularmente quanto à formação de inserção e controle da força de trabalho nos processos produtivos.

Com efeito, se por um lado, pudemos observar um número elevado de inovações em matéria de produtos, isto é, novos produtos, o grau de satisfação dos mesmos, bem como suas características e as possibilidades de diversificação produtiva, por outro, as mudanças estavam muito mais centradas na forma do processo de produção do que do produto.

Quanto às formações de produção, poderíamos destacar a utilização de equipamento flexível ou programável, capaz de cumprir diversas funções vinculadas não somente em distintos momentos do processo produtivo de um determinado bem, mas também, à capacidade de adaptar-se a modificações de um produto ou servir para participar na produção de outro bem.

As transformações das relações intra e interfirmas constituíam outra das chaves das novas formas de produção. As possibilidades abertas pelo desenvolvimento das telecomunicações e o processamento veloz da informação, assim como o custo relativamente baixo destes serviços induziu à reorganização das relações intra-firmas, permitindo uma maior interconexão e integração dos distintos momentos do processo produtivo, conduzindo à integração sistêmica de funções, alterando os padrões de configuração de plantas, papéis, tamanhos e localização das mesmas.

No caso das relações interfirmas, também as novas tecnologias permitiram o acesso a uma maior integração e interação, que entre outros fenômenos, induziu à "desverticalização" da população.

O paradigma de produção flexível pós-fordista ou neofordista, implicou na substituição das economias de escala pelas economias de "diversidade", já que se estruturou a partir de demandas segmentadas, de menor tamanho, com grande diferenciação de produtos e modelos, orientada a pautas de consumo individualizadas e baseadas em bens de obsolescência relativamente rápida, tanto funcional como tecnológica.

Esta foi a razão pela qual o tamanho da planta representativa do novo paradigma era substancialmente menor (se for medido em termos de pessoal ocupado), sem que ele implicasse necessariamente em menores níveis de inversão em capital fixo.

A reorganização do processo de trabalho, a partir da incorporação de novos recursos tecnológicos, determinou também a substancial modificação do perfil do operário industrial, de seus papéis e de suas relações com o equipamento e com os demais operários.

As novas tecnologias de produção motivaram a substituição da configuração taylorista de organização do trabalho. Esta estava baseada na especialização do operário, numa atividade predominantemente individual do mesmo e numa estrutura disciplinar hierárquica; enquanto os sistemas de produção emergentes requeriam um tipo de inserção do operário no processo produtivo 
que tendia à plurifuncionalidade e capacidade de adaptação do mesmo, assim como à constituição de grupos de trabalho semi-autônomos.

Estas mudanças significaram, por um lado, um certo processo de desqualificação e perda de postos de trabalho em geral, mas, por outro lado, também implicaram em certa recuperação da autonomia, iniciativa e capacidade de decisão e controle dos operários sobre o processo de trabalho.

A evolução do marco jurídico-político acompanhou tais processos. De fato, inicialmente verificamos nos países industrializados, e atualmente, nos países em desenvolvimento, diversos intentos de reformulação do Estado, baseados fundamentalmente na "degradação" da economia em geral, na privatização de algumas atividades produtivas que o Estado assumira durante o regime fordista, na adaptação do suporte legal que regia as relações sociais da produção, aos novos reclamos do capital (flexibilização do trabalho e minimização de conflitos) e no desmantelamento dos mecanismos que garantiam uma distribuição progressiva da receita.

No que tange a este último aspecto, entendemos que no discurso político o que apareceu como demanda de desregulação, na realidade, se traduziu em mudança na orientação e nos destinatários dos mecanismos regulatórios, que tendiam a reproduzir a complexidade estrutural que o Estado apresentava em relação à construção do novo modelo econômico e social; enquanto se constatava também o desaparecimento dos instrumentos distributivos e assistenciais de desenvolvimento e de previdência social.

Desta forma, o modo de regulação corporificada pelo Estado do Bem Estar, classicamente keynesiano e fordista, foi paulatinamente substituído pelo Estado neoliberal, adquirindo maior funcionalidade com as novas modalidades e necessidades estruturais da acumulação capitalista flexível.

A expansão do poder dos grupos econômicos, dos grandes consórcios exportadores e dos credores externos e a malha de relações pluriescalares que os mesmos conseguiram viabilizar, constituíram a contrapartida da declinação e/ou reorientação da capacidade regulatória do Estado Nacional.

Na América Latina, o processo teve início nos anos sessenta com a penetração maciça de certas políticas de compras do Estado, culminando com as atuais manobras de desmantelamento do Estado produtor de bens e serviços.

Finalmente, a transformação da estrutura e dos papéis do Estado Nacional está produzindo significativos impactos territoriais. Efetivamente, os Estados Nacionais ao se tornarem mais frágeis e com dificuldades de regularem as economias domésticas, motivaram uma significativa mudança na concepção de fronteira, seja pela integração institucionalizada e, mais ou menos voluntária, ou por simples satelização. 
Outra maneira de abordar este assunto, é o fato de atualmente, cada região, província, município e cidade tender a ser inserido diretamente na malha de relações multiescalares que caracteriza o capitalismo atual, que, para sua expansão, parece ter necessidade de vulnerabilizar de maneira crescente o caráter mediador da presença de Estados Nacionais intervencionistas e vigorosos.

As aludidas mudanças cederam lugar ao surgimento de novas estratégias e estruturas territoriais, devido à natureza do regime de acumulação emergente, que supõe a superação da lógica locacional fordista, fortemente concentradora no espaço. As necessidades estruturais do fordismo terminal, as possibilidades de fragmentação do processo produtivo através da introdução de novas tecnologias de produção, circulação e processamento da informação, assim como o auge, durante o final da década mencionada e princípios dos anos oitenta, de marcos legais amplamente favoráveis à inserção do capital em áreas periféricas seriam os elementos causais de certa tendência à dispersão geográfica dos meios de produção, seja ela visualizada à escala global ou nacional.

Paralelamente e cada vez mais, o novo modelo gerou nos países mais avançados certas tendências ao reagrupamento das unidades de produção com predomínio de formas concentradas, ainda que não necessariamente na medida imposta pela rigidez do modelo produtivo fordista, na sua necessidade de maximizar economias de escala e contiguidade espacial das etapas do processo produtivo, nem tampouco nas áreas tradicionalmente industrializadas sob esse modelo.

Tanto à escala nacional como global, o saldo do processo de reestruturação produtiva parece ser a desindustrialização (em termos relativos ou absolutos) das áreas industriais tradicionais e o surgimento ou revitalização de áreas de escasso desenvolvimento industrial fordista.

A nível nacional, a funcionalidade, que com as novas tecnologias abre-se às possibilidades de iludir mediante a deslocalização e/ou a relocalização, e a ação das organizações representativas dos trabalhadores determinaram o declínio das áreas que se estruturaram a partir do modelo fordista e a aquisição de vantagens comparativas para as regiões onde o fordismo não incidiu significativamente.

Obviamente, estas tendências estariam sinalizando processos incipientes, mas progressivos de reorganização ou alteração do modelo territorial fordista, como resultado da redefinição da divisão regional do trabalho.

Estes processos de formação de novos espaços industriais ou modificação das áreas industriais históricas devem-se não só a mudanças tecnológicas, de produção ou organizacionais. Ademais, se produziram como consequência do caráter e significação Inter setorial diferencial daqueles. Grandes regiões industriais foram edificadas em torno de atividades industriais que hoje estão em acentuado declínio (siderurgia, metalurgia, metal mecânica, têxtil, etc.), enquanto os setores emergentes (eletrônica, telecomunicações, novos materiais, química fina, biotecnologia, etc.) não tinham maior significado, ou compromisso com tais áreas. 
Pelo que acima foi exposto, observamos que as mudanças na estrutura do território não se verificaram apenas nas áreas mais dinâmicas do país, tais como o Sul e o Sudeste, mas foram também identificadas em regiões menos desenvolvidas, como é o caso do Nordeste brasileiro.

\section{Professora, por que sua opção pela região Nordeste do Brasil?}

A nossa opção pelo Nordeste do Brasil apareceu quando estávamos cursando o segundo ano da universidade, exatamente, quando assistíamos a aula sobre a Geomorfologia do Nordeste, explicada pelo Professor Doutor Aziz Ab’ Saber. Estávamos tão concentrada nas elucidações ministradas pelo professor que ele deu-se conta da nossa profunda atenção e, indagou-nos: por que você está particularmente interessada na aula de hoje, Beatriz? Respondemos-lhe que já estávamos nos inteirando da geomorfologia nordestina, porque tínhamos o objetivo de trabalhar naquela área do país. O Professor avizinhou-se da nossa carteira e, sorrindo, disse-nos que seria pouco provável que tal fato ocorresse porque, no seu pensar, nós logo iríamos nos casar e constituirmos nossa família. Ressaltamos-lhe que um casamento imediato não estava nos nossos planos e ele continuou sorrindo, incrédulo.

Todavia, em 1962, já formada e ministrando aulas no ensino secundário e, no Departamento de História da PUC de São Paulo, uma certa tarde, tocou o telefone e quem atendeu foi nosso pai. No momento, não estávamos em nossa residência e, tão logo chegamos, papai veio ao nosso encontro, dizendo-nos que o Professor Aziz precisava falar, urgentemente conosco e, havia marcado um encontro no dia seguinte, à tarde, nas dependências da Secretaria Geral da PUC de São Paulo. No dia subsequente, deparamano-nos, na Secretaria, com o Professor Aziz, acompanhado por um Senhor que nos foi por ele apresentado, como sendo o diretor da Faculdade de Filosofia, Ciências e Letras da Universidade Federal da Paraíba, o qual estava em São Paulo, buscando candidatos que tivessem o propósito de submeterem-se ao concurso público de provas e títulos, a ser realizado na faculdade de Filosofia da Paraíba, para o resgate de novos professores necessários ao quadro docente daquela instituição. Tratava-se do Professor Doutor Milton Paiva que disse-nos do intuito do Reitor da Universidade da Paraíba, de fundar o Departamento de Geografia, no âmbito da Faculdade de Filosofia. Assim sendo, os aprovados no futuro concurso seriam contratados para compor o corpo docente, do recém-criado Departamento de Geografia.

O Professor Aziz, após as apresentações, disse ao Professor Doutor Milton Paiva que nos ouvira falar no segundo ano da universidade, a respeito do nosso objetivo de trabalharmos no Nordeste brasileiro. Foi, então, que o Doutor Milton, indagou-nos, se estaríamos com a disponibilidade de submetermo-nos ao concurso de ingresso, na Universidade da Paraíba. A nossa resposta foi afirmativa e, tendo logrado pleno êxito no concurso, fomos aprovada e começamos o nosso trabalho naquela 
Universidade, no período compreendido entre 1963 até 1968, quando retiramo-nos de João Pessoa por defendermos ideias radicalmente opostas àquelas defendidas pelo, então, Estado Militar, que havia se estabelecido em nosso país.

O tempo passou, estivemos na Europa, em outros lugares do mundo, retornamos ao nosso país, trabalhando, na Secretaria de Economia e Planejamento do Estado de São Paulo e, posteriormente, na Universidade Estadual Paulista, no período compreendido entre 1978 até 1991. Ainda como docente, da UNESP de Rio Claro, certa ocasião, dialogando com uma orientanda potiguar, que fazia a sua dissertação de mestrado sob nossa orientação, dissemos a ela que o nosso grande desejo seria retornarmos ao Nordeste brasileiro.

Cerca de um ano depois deste diálogo, recebemos um telefonema da ex-orientanda, avisandonos que ocorreram, ao mesmo tempo, várias aposentadorias no Departamento de Geografia da UFRN e que, a direção do mesmo, instaurara um concurso público para o preenchimento das vagas disponíveis. Em fevereiro de 1992, partimos para Natal/RN e lá, submetemo-nos ao concurso público, visando o nosso ingresso no Departamento de Geografia, da referida instituição. Passamos em primeiro lugar, neste concurso e, no dia 29 de maio de 1992, assinamos o contrato de trabalho, passando a trabalhar no Departamento de Geografia da UFRN, no qual só retiramo-nos, por aposentadoria compulsória, em 20 de junho de 2008.

\section{Em que momento e como se deu essa opção?}

O Nordeste brasileiro é o lar dos nossos avós e dos nossos pais. Todos eles, principalmente os nossos pais, sempre chamaram a nossa profunda atenção pelo seu modo de pensar, ser e proceder, ao longo de suas vidas. Muitas vezes, surpreendemo-nos diante dos nossos pensamentos ao perguntarmo-nos o que teria essa região para ser o lugar de nascimento de pessoas absolutamente incríveis, como foram nossos pais e nossos avós. Assim, lá no íntimo da nossa mente e do nosso coração, não hesitamos em tomar a decisão de trabalharmos nesta região, berço daquelas pessoas especiais e singulares, no bom sentido da palavra. E, quando chegamos no Nordeste, ao visualizarmos o seu litoral deslumbrante, o seu sertão semiárido com belas paisagens, bem como os seres humanos que aí habitavam, a sua forma de falar, a sua cultura riquíssima e a sua sociabilidade e alegria, pensamos conosco: daqui não sairemos e daqui ninguém nos retirará.

\section{Professora Beatriz Pontes, explorando a sua larga e reconhecida experiência com relação aos movimentos epistemológicos mais recentes no âmbito do processo da história da Geografia brasileira, gostaríamos que a Senhora destacasse os principais avanços (teóricos e metodológicos) decorridos ao longo deste processo.}


Pelo que observamos, ocorreram vários avanços teórico metodológicos. Devemos salientar que quando, do advento da Geografia Crítica, respaldada na Teoria Marxista, baseada no Materialismo Histórico e Dialético, sentimo-nos, efetivamente, muito atraída por esse referencial teórico, no qual trabalhamos até hoje, apesar de não discriminarmos nenhum dos outros encaminhamentos teórico metodológicos implementados pelo pensamento geográfico internacional e nacional, porque, ao longo da nossa trajetória geográfica, trabalhamos com todas as outras metodologias, em função das consultorias, assessorias, representações em conselhos, além da própria atividade acadêmica, propriamente dita, em equipes pluridisciplinares. Entretanto, notamos que o próprio método dialético passou por revisitações, a partir do advento do Sistema Técnico-Científico-Informacional, em pleno período de uma globalização que, também, está em continuada transformação. Sentimos que os tempos acelerados, advindos das dotações de novas tecnologias, estabeleceram diferenças simultâneas, entre os referidos tempos acelerados e os tempos lentos que convivem na contemporaneidade, dando-nos muita margem de reflexão, quando abordamos a questão do território, sobretudo, sob a ótica da interface Natureza-Sociedade. Isto porque, a natureza está sendo vítima de processos de degradação que interferem, em grande escala, na existência humana, sobre a face da terra, exigindo-nos a busca de novos referenciais teóricos, nos quais estejam contempladas questões ecológicas e contextos identitários da condição humana.

Desta forma, comprovamos progressos no projeto teórico da complexidade, além de substanciais aprofundamentos na Geografia Comportamental e da Percepção, a qual se respalda numa base significativamente fenomenológica. Portanto, é como disse o Professor Milton Santos, no seu livro, "A Natureza do Espaço", não podemos mais resgatarmos, apenas, a lógica e a razão, mas, teremos que incluir, no nosso pensar científico, igualmente, a emoção. Além desses aspectos, teremos que considerar as chamadas "Terras Incógnitas" que abrangem os estudos do Quarto Mundo, O Lado Obscuro da Globalização, A Crise da Guerra, os Emigrantes e Refugiados, os Agentes Pós-Políticos: Ética e Ação Humanitária, além dos "Lugares Incógnitos" representados pelo sistema prisional, pelo sistema dos manicômios, pelos campos de refugiados, pelos lugares onde ainda existem o trabalho escravo, bem como os territórios da exclusão e do extermínio, frutos de Guerras Civis contemporâneas. Devemos incluir também, neste quadro de referência, os lugares da pobreza nacional e mundial e os territórios da fome permanente que são totalmente esquecidos até mesmo, pela mídia contemporânea. Essas “Terras Incógnitas" representam novos desafios para as reflexões e avanços de projetos teórico metodológicos que tenham condições de explicar tais questões que, muitas vezes, não podem ter uma explicação única, tendo em vista que o mundo é sumamente heterogêneo e multifacetado. Portanto, as fragmentações e as identidades constituem temas desafiadores para o pensar geográfico contemporâneo, sob uma ótica teórico metodológica. 
Finalmente, não podemos ignorar métodos e técnicas que, atualmente, são importantes para os desvendamentos dos quadros geográficos, tais como: o avanço da aerofotogrametria e da aerofotointerpretação, o significado dos mapas elaborados a partir de imagens de satélite e de radar e a informática, através dos sistemas de informação geográficos que estão progredindo em ampla escala, tendo em vista o aperfeiçoamento e o advento de novas técnicas que estão surgindo, relevantemente, nos tempos atuais e, que nos fazem repensar, todo o quadro geográfico diante dos nossos olhos.

\section{Quais os desafios que ainda permanecem no sentido de avançarmos ainda mais em termos de um trabalho geográfico efetivamente adequado ao atual quadro de referência da sociedade contemporânea?}

No que concerne a esta questão, pensamos que temos pela frente o desafio do amplo aperfeiçoamento de métodos investigatórios, na esfera socioeconômica, porquanto a natureza desta realidade, frequentemente, nos inclina à opção de métodos qualitativos e de pesquisa participante que, ao nosso ver, são aqueles que poderão nos dar condições de verificarmos a realidade concreta que está posta diante das nossas pessoas.

Entendemos que a pesquisa científica, nas Ciências Humanas é absolutamente desafiadora e, sem dúvida, está a requerer dos cientistas sociais novas reflexões que gerem métodos que nos avizinhem o mais possível da efetiva realidade. Trata-se de uma questão difícil, principalmente pelo advento das chamadas "Terras Incógnitas", que já foram aludidas, precedentemente, isto é, pesquisar nas esferas já acima referenciadas, não é uma tarefa fácil, pois, exigem grande treinamento e, sobretudo, no âmbito comportamental das pessoas que se dispuserem a tais pesquisas que denotam muitas dificuldades, mas que nos levariam a um conhecimento apurado de realidades bastante esquecidas.

\section{Como a Senhora define os movimentos sociais? Qual o papel da Geografia nos movimentos} sociais, e mais especificamente nas lutas e resistências sociais?

Entendemos os Movimentos Sociais contemporâneos como formas dos grupos humanos reivindicarem os seus direitos, protestarem com veemência sobre questões com as quais não concordam, bem como movimentos que possam propor novas ideias, novos comportamentos, asseverando suas identidades, além do seu direito de conviver em sociedade de forma digna e saudável e, sobretudo, o seu direito ao território, no qual estão estabelecidos e construíram o seu trabalho, a sua cultura e, por conseguinte, as suas identidades. 
No nosso entendimento, a Ciência Geográfica tem, em relação aos Movimentos Sociais, o maior propósito de estudar os mesmos ligados ao território e à territorialidade. Assim sendo, pensamos que se pudermos analisar, detidamente, os diferentes conteúdos das "Terras Incógnitas", teremos plenas condições de observarmos, num primeiro momento, qual é a relação da sociedade no seu território, quais as transformações nessas relações estabelecidas ao longo do tempo e como as sociedades reagem, de formas diferentes, na busca do seu território e a salvaguarda das suas respectivas identidades.

8. Em sua opinião, é possível enxergar amadurecimento na sociedade brasileira em relação à sua participação no planejamento e gestão públicos?

Achamos que infelizmente, existem no âmbito da sociedade brasileira, "ilhas" de pessoas altamente qualificadas que têm a plena habilitação e consciência para o desempenho do planejamento e da gestão públicas. Todavia, se levarmos em consideração as condições nas quais se encontram, atualmente, a educação nacional, ponderamos que a expressão majoritária da população brasileira carece de conhecimentos circunstanciados, a partir dos quais teriam amplas vantagens de exercerem com êxito e categoria, o planejamento e a gestão públicos. No quadro atual, consideramos que estamos muito longe de lograrmos um nível de maior consciência e amadurecimento coletivos e democráticos para o exercício das atividades acima referidas.

\section{Considerando suas pesquisas e, portanto, sua larga e profícua experiência no âmbito da Geografia Política, a Senhora poderia definir o que significa este campo do conhecimento (geográfico) no mundo contemporâneo?}

No mundo contemporâneo, consideramos a Geopolítica e/ou a Geografia Política, envolvidas com outras temáticas relevantes, quais sejam as "Novas Terras Incógnitas". Consideramos tais aspectos muito próximos à necessidade de abordagens teóricas que contemplem as questões de identidade, território e política, o retorno ao lugar, a dimensão territorial dos nacionalismos, geopolítica e meio ambiente, o discurso ambientalista e seus antecedentes, a evolução do conhecimento referente aos discursos e às instituições ambientais, meio ambiente, desenvolvimento sustentável e sistema mundial.

Além das supracitadas abordagens geopolíticas contemporâneas há, todavia, outras que merecem pesquisas aprofundadas: a questão Russo-Ucraniana; a guerra civil e a emigração síria; as relações contemporâneas entre EUA e Cuba; as questões atuais referentes ao terrorismo, envolvendo os EUA, o Egito e outras nações do Golfo Pérsico, em relação ao Qatar; as questões envolvendo os EUA 
e o desempenho da Coreia do Norte em ações nucleares; a crise hídrica e a sustentabilidade no mundo atual; a mobilidade urbana e os problemas dela decorrentes; o Estado Islâmico e a ONU; a depressão ao nível psicológico e o uso de medicamentos; o movimento feminista; a construção pela China de Ilhas Artificiais, nos mares do Sul da China e o processo de militarização das referidas ilhas, bem como os problemas internacionais decorrentes da iniciativa chinesa; o espectro da fome mundial, sobretudo em alguns países, como por exemplo, o Sudão do Sul, a Somália e Bangladesh; a atual posição do governo dos EUA nas esferas interna e internacional; a ampliação do terrorismo e dos movimentos de direita no mundo contemporâneo; os problemas relativos aos equipamentos e à formação de recursos humanos referentes à saúde e à educação; o significado contemporâneo do Oceano Pacífico na política e na economia do mundo atual; a diminuição relativa do poder norte-americano, tendo em vista o aumento de poder de outras nações, entre elas, a China e a Rússia; o tráfico de pessoas, de drogas e de armas, no presente e as desigualdades identificadas nos BRICS e a posição dessas nações no cenário internacional.

Torna-se difícil explicarmos a realidade Geopolítica neste início de milênio, uma vez que uma série de transformações do Sistema Mundial modificaram a sua aparência e seu funcionamento e inutilizaram alguns dos instrumentos habituais da Geopolítica.

Todavia, é este mundo em transformação e esta dificuldade que fazem com que a Geopolítica Contemporânea seja altamente significativa, aliás, como aquela que há pouco mais de um século, Ratzel ou Makinder começaram a construir.

O desabamento do Cenário do Aço significou o fim da Guerra Fria, do confronto Leste/Oeste, mas, outros dois processos já estavam em curso há duas décadas e, lentamente, corroíam o Sistema: o da globalização dos fluxos e decisões econômicas e o da fragmentação das identidades.

Não se trata de processos interdependentes, pelo contrário. Como afirmam, Benko e Lipietz, em seu livro "As regiões que ganham (1994)", a relação entre globalização e identidade - eles falam de "localização" - desenha um Cinturão de Moebius, sem início nem fim.

Com estes três processos, como já ocorrera no princípio do século $\mathrm{XX}$, o mundo mudou: a separação Leste/Oeste se desfez; a posição Norte/Sul deixou de ser um Eixo preciso; o Estado e a soberania cederam grande parte de seu destaque político, social e econômico e as escalas de poder reestruturaram-se de cima a baixo, ou melhor, tudo aquilo que utilizava a geopolítica para interpretar o mundo e a sua organização, tornou-se obsoleto.

Podemos dizer que se trata de uma crise da geopolítica, compartilhada com outras ciências sociais e que dá lugar, além de uma boa dose de confusão, a uma rica diversificação dos caminhos e métodos de pesquisa. É por isso, por essa capacidade de criar fórmulas explicativas magistrais, que existe quem fale de um Sistema Mundial em desordem, o que é aliás o que tentamos explicar no presente. Trata-se de um mundo com mais atores, mais diferenciados e menos estáveis do que antes. 
É certo, também, que quando já não parecia possível, reapareceram os "territórios ou lugares incógnitos", territórios desconhecidos ou fora de controle, não institucionalizados, que contribuem para a instabilidade e a incerteza do Sistema Mundial (crime organizado, marginalidade social, pobreza extrema). Estas "terras incógnitas" surgem à margem do Sistema Mundial, como boa parte da África, em meados do século XX. Porém, aí está a novidade, elas são, por sua vez, resultado dele e, inclusive, vivem dele.

Se discutirmos a desconcentração, o caos e a complexidade devemos posteriormente, observarmos a reconstrução da Geopolítica. Nessa reconstrução são tratados novos fenômenos, ainda que não todos, que caracterizam o mundo contemporâneo, e sobre estes, voltamos o nosso olhar para a geopolítica, buscamos a sua dimensão territorial, partindo da premissa de que esta dimensão é, novamente, determinante. Determinante para a interpretação da construção de identidades coletivas que possuem tanto em sua origem, como em seus argumentos, o lugar, isto é, a reivindicação da diferenciação espacial como mecanismo de coesão e de presença no Sistema Mundial Global.

Por outro lado, é lógico que a perspectiva ambiental manteve a geopolítica mundial e a sua análise converteu-se em uma das linhas fundamentais de pesquisa e da reflexão da mesma, talvez, uma nova chave de leitura, como foi a Guerra Fria, há algumas décadas. Assim como aconteceu com o confronto entre comunismo e capitalismo, trata-se de uma chave vital, no sentido literal do termo: a humanidade aposta seu futuro no meio ambiente, em sua proteção e na melhora de sua gestão.

\section{Considerando o verdadeiro papel que uma universidade deve desempenhar em prol do desenvolvimento territorial de uma nação, que papel a Senhora entende estar sendo desenvolvido pela universidade pública no Brasil?}

Quanto a esta questão, tivemos a oportunidade de observar há cerca de dois decênios, a preocupação do nosso país com a construção de políticas nacionais de ordenamento territorial, políticas regionais e de fronteiras. Lembramos que essas políticas tiveram o consórcio de alguns grandes geógrafos, como Bertha Becker e Lia Osório de Andrade, ambas da Universidade Federal do Rio de Janeiro.

Da mesma forma, constatamos, também, a preocupação do Estado brasileiro quanto à sua área costeira, claramente expressa no Programa Nacional do Gerenciamento Costeiro. Essa política, diretamente afeta ao Ministério do Meio Ambiente, também contou com a presença de geógrafos do estofo de Bertha Becker e Antônio Carlos Robert de Moraes (USP).

Os estudos que precederam a formulação das referidas políticas foram circunstanciados e sérios. Infelizmente, no período atual, o gigantesco trabalho que foi desenvolvido nos dois decênios precedentes permanecem estagnados e o que observamos são intervenções pontuais nas fronteiras, no 
território nacional e na área costeira para o atendimento de reclamos nem sempre dignos de grande confiança, evidenciando como está claro, o período de turbulência que ora vivenciamos.

Convém ainda ressaltar que, lamentavelmente, os recursos do Estado brasileiro para dar suporte a um pagamento digno dos docentes e pesquisadores universitários, para a aquisição de equipamentos tecnológicos que agilizem a pesquisa e a negligência, no que tange à educação nacional como um todo, constituem problemas gravíssimos, aos quais estamos, no presente, assistindo.

Lamentavelmente, devemos dar como exemplo a Universidade do Estado do Rio de Janeiro, o nosso estado de nascimento, pelo qual nutrimos grande apreço e que está completamente sucateada, resultando num crescente número de docentes e discentes seriamente abalados, do ponto de vista psicológico.

\section{Qual é o quadro atual da Geografia Política e da Geopolítica (se é que podemos separar estas suas dimensões das relações entre espaço e poder) hoje, no mundo e no Brasil?}

Pensamos que a Geopolítica está profundamente comprometida com o estudo das relações entre espaço e/ou território e poder. Todavia, na atualidade, existem elementos fundamentais que norteiam estes estudos: a estratégia, a logística, a jurisprudência, incluindo também, as relações humanas e de poder nas realidades territoriais que configuram as guerras, os conflitos ou a paz, não ignorando os atos sociais e seus desdobramentos diante dos três quadros precedentes e, sobretudo, com um forte conteúdo de preservação das identidades diferentes dos povos, na busca de uma possível convivência comum, porém, diferenciada.

No mundo contemporâneo, identificamos conflitos que se prolongam, através de guerras civis, as quais se aprofundaram com o advento do terrorismo e que, muitas vezes, dependendo da área do mundo onde concretamente se realizam são quase que esquecidas pela comunidade mundial.

Vemos que o mundo contemporâneo apesar de existirem Estados que procuram equacionar os grandes problemas, através do diálogo, do entendimento e da diplomacia, outros assumem posturas radicais e ameaçadoras que, entretanto, não têm resolvido alguns grandes problemas no âmbito destes Estados, bem como na esfera mundial.

Percebemos além disso, que tanto na esfera planetária, quanto em nosso país, não existem somente instrumentos efetivos que realizam a violência, mas esta reside nas próprias ações humanas, através principalmente, do dinheiro, da corrupção e da contravenção perpetradas no âmbito da própria sociedade, desarticulando estruturas econômicas, sociais e políticas que poderiam estar em pleno funcionamento em benefício da própria sociedade brasileira ou mundial. 


\section{Qual sua visão sobre a chamada "crise" econômica brasileira na atualidade e seus impactos na continuação da implantação das políticas públicas no Brasil?}

Acompanhando criteriosamente o encaminhamento da economia brasileira, observamos que algumas medidas relativas à inflação e a tendência à diminuição gradual dos juros, o crescimento da atividade do agronegócio, bem como o seu posicionamento no PIB, o aumento das exportações e, um leve impulso observado nas importações, poderiam melhorar a situação da economia do nosso país, além de um crédito bancário que prodigalizasse melhores condições de financiamento para que o povo brasileiro tivesse condições de melhor equacionar as suas necessidades básicas, podendo ainda, sair lentamente da inadimplência. Além desses aspectos, a possibilidade de maiores investimentos internos e externos poderiam, sem dúvida, alavancar a nossa economia.

Entretanto, essa dinâmica deveria ser acompanhada da observação detida do quadro social, fato que não tem ocorrido. Além do que foi acima exposto, devemos salientar o desemprego de quase 14 milhões de pessoas, além dos discutíveis conteúdos que envolvem as Reformas da Previdência Social, do Trabalho, da Política e da Tributação, as quais não estão adequadamente direcionadas para os interesses democráticos da sociedade brasileira.

Assim sendo, se o povo brasileiro não sair às ruas para defender os seus direitos, ele estará fadado a vivenciar, posteriormente, situações muito difíceis no universo do trabalho, da previdência social, da política e do quadro financeiro. Consideramos que o povo brasileiro não está adequadamente informado sobre o que está ocorrendo, em torno de tais reformas, no âmbito do Congresso Nacional. Temos assistido a calorosos debates na CPI da Previdência Social, coordenada pelo Sr. Senador Paulo Pain, além de outros debates em Comissões Setoriais que discutem as questões em tela, nas quais são chamados especialistas de diferentes atividades profissionais e de diferentes correntes de opinião críticas. 0 que podemos aferir de toda essa nossa experiência, ouvindo atentamente, o que está sendo discutido nas comissões da Casa do Legislativo, deixaram-nos alarmada porque os detalhes, as minudências e os problemas identificados no conteúdo de tais reformas, não foram adequadas e claramente colocadas para o povo brasileiro.

Tendo em vista tal contexto, as políticas públicas daí decorrentes não poderão ser confiáveis porque o processo de corrupção em curso vem dando ampla margem a que empreiteiras e outros grandes empresários do país, dialoguem diretamente com o poder constituído, logrando indevidamente, benesses altamente discutíveis que comprometem políticas públicas já existentes, as quais nem sequer são implementadas como seria desejável. 


\section{Com relação ao mundo e ao Brasil, em particular, a Senhora se colocaria como uma Intelectual otimista ou pessimista? Por quê?}

Atentando-se ao quadro global e ao nosso país em particular, apesar de sermos habitualmente otimista, devemos ponderar que em decorrência da realidade atual nos achamos bastante reticentes porque não estamos acreditando no desempenho do governo nacional, bem como nos estrangeiros, causando-nos grande preocupação, o atual governo que preside os EUA, o qual tem assumido posições discutíveis que em nada têm contribuído para a resolução de problemas políticos, econômicos e sociais perversos que estão a contaminar os Estados e, neles inseridos a humanidade heterogênea contemporânea.

14. Professora, por último, mas não de menor importância, o que é ser uma Geógrafa-Cidadã? A Senhora se coloca como tal? Por quê?

No nosso entendimento, um geógrafo cidadão deve ter experiência completa em sua área de atuação, isto é, não deter somente a experiência no âmbito da universidade, na qual criamos o saber geográfico e discutimos este mesmo saber já consagrado, além de estarmos atenta à formação humanística dos nossos jovens.

Complementando essa grande tarefa, faz-se mister observar o que chamaríamos a ciência aplicada que pode ser amplamente encaminhada através de assessorias, consultorias, atividades técnicas em instituições públicas ou privadas e conselhos comunitários junto às prefeituras, além de uma continuada ação prática que poderá ser levada a termo, quer através de projetos de extensão de âmbito universitário, quer através de ações voluntárias junto a Conselhos de Bairros, a organizações preocupadas com questões sociais, além da possibilidade de encamparmos movimentos sociais que atuam, presentemente, nas ruas de cidades brasileiras, reivindicando direitos humanos, direito ao trabalho, direito a uma previdência social que absorva os direitos do povo trabalhador que é aquele que coloca efetivamente o Brasil em movimento. Sem o trabalho, o que seria do lugar, da cidade, da região ou de um Território Nacional?

Ao longo da nossa carreira fizemos parte de Conselho Municipal de Saúde, Conselho Comunitário junto à Prefeitura Municipal de Rio Claro, Conselho do Patrimônio Histórico, Arqueológico, Artístico e Turístico vinculado à Secretaria de Cultura do Estado de São Paulo. Demos consultoria ao governo do Estado do Rio Grande do Norte sobre o Zoneamento Ecológico-Econômico, referente ao Programa Estadual do Gerenciamento Costeiro, do referido Estado e demos uma longa consultoria, de cerca de três anos, à Prefeitura Municipal de Canguaretama (RN), efetuando o Plano Diretor, sete Planos Setoriais, Programas e Projetos implementados, posteriormente, pela referida 
prefeitura. Também demos assessoria ao bairro de São João, situado na periferia da cidade de Rio Claro (São Paulo), no qual tivemos uma experiência riquíssima relativa ao nosso trabalho que envolvia o saneamento básico daquele bairro.

Finalmente, devemos ressaltar que essa profícua convivência com o povo brasileiro, nas diferentes instâncias acima aludidas, nos ofereceram a grata satisfação de não apenas emitirmos os nossos conhecimentos, mas aprendermos o maravilhoso saber popular, o qual guardamos até hoje, na nossa mente e no nosso coração.

Portanto, nos consideramos uma geógrafa cidadã porque ao longo de toda a nossa carreira, através dos projetos de extensão universitários e outras atividades voluntárias, tivemos o tempo todo junto à população do nosso país e procuramos, na medida do possível, ajudar essa população para a melhoria das suas condições de vida. 